\title{
Pedagogia da ameaça: uma análise dos padrões comunicativos de socialização no WhatsApp bolsonarista
}

\author{
Pedagogy of threat: an analysis of communicative patterns of socialization in Jair Bolsonaro's \\ WhatsApp support groups
}

\section{Pedagogía de la amenaza: análisis de patrones comunicativos de socialización en grupos de apoyo al presidente Jair Bolsonaro en WhatsApp}

Rodrigo Pelegrini Ratier*

\section{Resumo}

O objetivo deste trabalho é analisar aspectos da socialização nos grupos públicos bolsonaristas no aplicativo WhatsApp. O foco são os padrões comunicativos recorrentes nesse espaço. Utilizando como material de análise mensagens textuais e visuais, animações, memes e vídeos veiculados em comunidades virtuais de apoio ao presidente Jair Bolsonaro, indica-se a existência de uma "pedagogia da ameaça", com fluxo comunicativo centralizado, ausência de debates e nenhum espaço para o contraditório. A análise de conteúdo aponta intensa circulação de mensagens apoiadas em três padrões comunicativos fundamentais: 1- binômio amigo-inimigo, 2- apelo à emoção e 3- estratégias de desinformação. Defende-se que a plataforma virtual em tela se configura como uma mídia ideológica na acepção proposta por Thompson (1995), a de sentido a serviço do poder. Ao emular um estado de ameaça constante, o WhatsApp bolsonarista ambiciona reunir, alertar e convocar a militância para a defesa do presidente diante de perigos e intimidações.

Palavras-chave: WhatsApp; socialização; nova direita; bolsonarismo.

\section{Abstract}

The aim of this work is to analyze aspects of socialization in WhatsApp public groups that support Brazilian president Jair Bolsonaro. The focus is on the recurrent communicative patterns in this space. Considering textual and visual messages, animations, memes and videos published in pro-Bolsonaro digital communities, we point to the existence of a "pedagogy of threat", with centralized communicative flow, absence of debates and no space for contradictory opinions. The content analysis indicates intense circulation of messages based on three main communicative strategies: 2-friend-enemy binomial; 2- appeal to emotion; 3- misinformation strategies. It is argued that the virtual platform on screen is configured as an ideological medium in the sense proposed by

Recebido em: 30/07/2020 - Aprovado em: 09/06/2021

http://dx.doi.org/10.5335/rep.v28i1.11465

\footnotetext{
Doutor em educação pela Universidade de São Paulo. Pesquisador do Grupo de Pesquisa Práticas de Socialização Contemporâneas (GPS-FEUSP) com participação no Programa de Doutorado Sanduíche no Exterior, fomentado pela Capes, na Université Lumière Lyon 2. Professor assistente do curso de jornalismo da Faculdade Cásper Líbero (FCL). Jornalista e professor universitário na Faculdade Cásper Líbero. Colunista na plataforma ECOA | UOL (https://www. uol.com.br/ecoa/colunas/rodrigo-ratier/). Coordenador do blog coletivo Entendendo Bolsonaro (entendendobolsonaro.blogosfera.uol.com.br). Fundador e gestor do curso online contra fake news Vaza, Falsiane (www.vazafalsiane. com). Orcid: https://orcid.org/0000-0001-9733-7563. E-mail: rratier@gmail.com
} 
Thompson (1995), that of meaning in the service of power. By emulating a state of constant threat, the Bolsonarist WhatsApp aims to gather, alert and summon militancy to defend the president in the face of dangers and intimidation.

Keywords: WhatsApp; socialization; alt-right; Jair Bolsonaro.

\section{Resumen}

El objetivo de este trabajo es analizar aspectos de la socialización en grupos públicos de apoyo al presidente brasileño Jair Bolsonaro en WhatsApp. La atención se centra en los patrones comunicativos recurrentes en este espacio. Utilizando como material de análisis mensajes textuales y visuales, animaciones, memes y videos difundidos en comunidades virtuales, se indica la existencia de una "pedagogía de la amenaza", con un flujo comunicativo centralizado, ausencia de debates y sin espacios para opiniones opuestas. El análisis de contenido muestra una intensa circulación de mensajes sustentada en tres patrones comunicativos fundamentales: 1- binomio amigo-enemigo, 2- apelación a la emoción y 3- estrategias de desinformación. Se argumenta que la plataforma virtual se configura como un medio ideológico en el signifcado propuesto por Thompson (1995), el de sentido al servicio del poder. Al emular un estado de amenaza constante, los grupos de apoyo de Bolsonaro tienen la intención de reunir, alertar y convocar a la militancia para defender al presidente ante los peligros y las intimidaciones.

Palabras clave: WhatsApp; socialización; nueva derecha; Jair Bolsonaro.

\section{Introdução}

O presente estudo, de caráter exploratório, dá continuidade à pesquisa desenvolvida desde 2018 sobre o WhatsApp bolsonarista por este autor. Insere-se no contexto de socialização plural (LAHIRE, 2002, 2004, 2012) e considera a importância da mídia na circulação de valores, padrões e formas de comportamento (SETTON, 2004, 2012). Como as demais instâncias de socialização da contemporaneidade - família, escola, igreja, trabalho etc. -, apresenta referenciais identitários, articulados pelo indivíduo, por vezes tensa e conflituosamente, em diferentes combinatórias. Resultam em disposições de habitus híbridos, não necessariamente homogêneas ou coerentes, acionadas conforme os contextos de ação (SETTON, 2002, 2005, 2009).

Do ponto de vista da socialização contemporânea, as mídias são espaços educativos, na medida em que disseminam informações e valores que auxiliam a estruturação de modos de ser, agir e pensar nos indivíduos. Educação, aqui, não designa forçosamente processo virtuoso ou restrito à escolarização formal. Considera-se o entendimento ampliado proposto por Libâneo (1998) para reconhecer que as mídias possuem uma função pedagógica e, muitas vezes, ideológica (SETTON, 2012).

Educação é o conjunto das ações, processos, influências, estruturas, que intervêm no desenvolvimento humano de indivíduos e grupos na sua relação ativa com o meio natural e social, num determinado contexto de relações de grupos e classes sociais (LIBÂNEO, 1998, p. 22). 
Discutir a natureza pedagógica de uma mídia, o WhatsApp, faz parte do escopo amplo deste estudo. $\mathrm{O}$ aplicativo se insere no contexto de ascensão das redes sociais, que levou a extensas transformações na produção e adaptações nos comportamentos de consumo tanto de indivíduos quanto de instituições sociais. Em uma perspectiva mais "integrada", McNair (2009) aponta que o desenvolvimento tecnológico potencializou as condições para uma democracia participativa sem precedentes. Em uma visão menos edulcorada, Jenkins (2006) enfatiza que a audiência passa a ser ativa, barulhenta, migratória, menos leal e socialmente conectada, redesenhando as regras por meio das quais a própria vida cívica opera. Num polo "apocalíptico", Han (2018), define a mídia digital como uma mídia de afetos, de uma cultura de falta de respeito e de indiscrição, fracamente ocupado pelo poder e pela autoridade. Reflexões que, desde um ponto de vista sociológico, apontam para o aprofundamento de um universo de autoridades múltiplas (LAHIRE, 2012), em que os sistemas de saberes peritos se encontram em crise e convocam, cada vez mais, a reflexividade individual nos processos de socialização (GIDDENS, 1991, 1997).

Em trabalho anterior (RATIER, 2020b), procuramos demonstrar as configurações fundamentais da rede de grupos públicos bolsonaristas no WhatsApp. A topologia das redes indica conjuntos de grupos fortemente interconectados, tanto por meio de convites para participação em outras comunidades quanto pela similitude dos conteúdos disseminados. Surgiram também indícios de centralização na produção de informação e de mecanismos de controle das heresias, com o banimento, pela ação dos administradores de grupos, dos indivíduos que apresentassem opiniões contrárias à defesa do presidente. Em outro lugar (RATIER, 2020a), aprofundamos a análise desses achados, confirmando a existência de uma "elite falante" - pequeno grupo de usuários que domina a produção de mensagens -, a predominância de postagens encaminhadas ou copiadas e a baixa qualidade da informação circulante, com predomínio de perfis em redes sociais ou sites hiperpartidários simpáticos ao presidente.

No presente estudo, a intenção é identificar, classificar e analisar as formas simbólicas predominantes e os padrões comunicativos prevalentes nos grupos bolsonaristas. Considerando a pedagogia como uma teoria prática da educação (DURKHEIM, 1965), buscam-se observáveis da materialização do ato educativo no aplicativo em tela. Para tanto, apoiamo-nos na hipótese de Cesarino (2019a) de que as funções comunicativas no ecossistema bolsonarista poderiam ser reduzidas a poucas estratégias elementares que visariam, de um lado, a reforçar a conexão entre o "líder" e o "povo" e, de outro, a estabelecer uma fronteira amigo-inimi- 
go, atribuindo aos adversários políticos afetos negativos - medo, repulsa, pânico. Defende-se que a reiteração de tais estratégias conforma o que denominamos de "pedagogia da ameaça", ambicionando reunir, alertar e convocar a militância para a defesa do presidente diante de perigos e intimidações.

O artigo se encontra dividido em seis seções. Esta introdução e uma conclusão; a fundamentação teórica, em que discute-se a natureza do WhatsApp, apresenta-se o fenômeno da "nova direita" brasileira em geral e do bolsonarismo em particular, culminando com sua atuação digital e a instrumentalização do WhatsApp para fins políticos; a metodologia de pesquisa; a apresentação dos resultados; a discussão dos achados, em que se sublinham os três padrões comunicativos mais recorrentes no conteúdo disseminado nos grupos analisados: 1- apelo à emoção; 2- binômio amigo-inimigo; 3- estratégias de desinformação. A análise recupera a influência da psicologia de massas em regimes autoritários (ADORNO, 2020; REICH, 1988) e a contribuição das teorias políticas de Laclau (2013) e Schmitt (2009), para amparar a hipótese de uma mídia ideológica na definição proposta por Thompson (1995), a de sentido a serviço do poder.

\section{Fundamentação teórica}

Mais bem-sucedido aplicativo de troca de mensagens no mundo, o WhatsApp se disseminou pelo mundo seguindo a popularização dos smartphones e as velocidades crescentes de conexão à internet. Lançado em 2009, foi arrematado em 2014 pelo Facebook por 19 bilhões de dólares. É uma das redes sociais que mais crescem no mundo. Segundo dados da companhia proprietária, atingiu 2 bilhões de usuários, atrás apenas do próprio Facebook, que possui 2,5 bilhões de contas ativas. No Brasil, são cerca de 130 milhões de usuários.

Formalmente, o aplicativo rejeita ser classificado como rede social. A definição oficial é de um serviço de mensagens instantâneas, desenvolvido para interações um a um (WHATSAPP, 2019). Para afastar o qualificativo, a empresa afirma que $90 \%$ das mensagens são trocadas entre dois usuários. Os outros $10 \%$ são disseminados em grupos, funcionalidade criada em 2011 para proporcionar comunicação coletiva. Podem abrigar até 256 contatos telefônicos e assumir três tipos diferentes: lista de transmissão, de caráter unidirecional, em que apenas os administradores podem publicar; grupos fechados, com contatos inseridos manualmente pelos administradores; e grupos públicos, quando o administrador publica o endereço 
de acesso ao grupo em páginas da internet ou o envia para contatos convidados. Qualquer pessoa que possua o link pode acessar um grupo dessa natureza.

A bibliografia afirma que a introdução da comunicação coletiva alterou a natureza bilateral do aplicativo (GARIMELLA; TYSON, 2018; SEUFERT et al., 2016). Farooq (2018) indica a facilidade de criar e compartilhar conteúdo e a mobilidade do WhatsApp como aspectos favoráveis para atingir grandes audiências. Já Vieira et al. (2019) identificam semelhanças entre a disseminação de mensagens pelo aplicativo e mídias tradicionais, como rádio e TV.

Há registros do uso de grupos de WhatsApp para a comunicação e propaganda política em diversas partes do mundo (FAROOQ, 2018). No Brasil, o aplicativo vem sendo utilizado mais amplamente pelo espectro político denominado de campo antipetista (RIBEIRO; ORTELLADO, 2018), nova direita (DUDA DA SILVA, 2018) ou extrema-direita (MIGUEL, 2018). Miguel (2018) enxerga a um só tempo elementos de aglutinação (libertarianismo econômico, fundamentalismo cristão e anticomunismo) e heterogeneidade, afirmando se tratar da confluência de grupos diversos em união pragmática contra um inimigo em comum - ou inimigos, a "ideologia de gênero" e o "avanço do comunismo", segundo Kalil (2018), ou ONGs e movimentos sociais, partidos de esquerda e movimentos identitários, conforme Ribeiro e Ortellado (2018).

Visões otimistas do aplicativo como lugar de discussão democrática, horizontal e plural têm sido problematizadas pela bibliografia. Christie (2019) aponta inclinação à polarização política, à autorradicalização e à distribuição de informações falsas. Por prisma semelhante, Litzendorf Netto e Peruyera (2018) enxergam esse tipo de estratégia como ferramentas de propaganda política na internet. Resende et al. (2019) nomeiam como "guerra de informação" a disseminação de desinformação durante a campanha presidencial de 2018. Na ocorrência mais aguda, a jornalista Patrícia Campos Mello noticiou enviou massivo de propaganda contrária ao candidato Fernando Haddad (PT). A ação, supostamente financiada por empresários simpáticos ao bolsonarismo, pode ter impactado centenas de milhões de usuários e vedada pelos termos de uso do aplicativo e pela legislação eleitoral (CAMPOS MELLO, 2018). Cerca de um ano depois, o WhatsApp reconheceu o uso impróprio do aplicativo (CAMPOS MELLO, 2019).

A ação não se confunde com os grupos públicos bolsonaristas. Construídos e mantidos por apoiadores desde antes das eleições, tornaram-se canais importantes de comunicação do então candidato e atual presidente, sendo parte de um ecossistema digital que Piaia e Alves (2019) classificam como "rede de comunicação 
subterrânea”. Em 2019, diversos estudos indicaram que tal rede seguia ativa (NEMER, 2019) e mesmo em crescimento (RATIER, 2020b).

Em termos topográficos, a aparente planitude da rede de grupos supostamente horizontais e autônomos contrasta com a centralização dos fluxos comunicativos. Nossas pesquisas anteriores (RATIER, 2020a, 2020b) dão conta de que apenas uma pequena parcela dos integrantes é responsável pela grande maioria das mensagens. Estas, por sua vez, reproduzem argumentos vocalizados pelas figuras mais visíveis do bolsonarismo - parlamentares da base, membros do governo, jornalistas, blogueiros e youtubers alinhados e o próprio clã. Durante as eleições, a campanha de Bolsonaro vendeu a ideia de uma militância digital orgânica, apoiando voluntariamente o então candidato. A tese se fragilizou com a revelação da existência de um suposto "gabinete do ódio" (ARBEX; URIBE, 2019). Trata-se de estrutura, cuja existência sempre foi negada pelo governo (WAJNGARTEN, 2020), liderada pelo vereador licenciado Carlos Bolsonaro, o "filho 02" do presidente.

Composto por um trio de assessores especiais da presidência e instalado no terceiro andar do Palácio do Planalto, o gabinete do ódio seria responsável pelas principais linhas narrativas de defesa do governo e de ataque aos adversários. Forneceria tanto insumos prontos para a replicação nas redes quanto inspiração para as produções da militância de carne e osso, ávida por ser compartilhada por parlamentares ou quem sabe pelo próprio presidente. Evidencias concretas da atuação do grupo surgiram em julho de 2020, quando o Facebook removeu uma rede com 73 contas, ligadas ao gabinete presidencial, a filhos de Bolsonaro e a deputados bolsonaristas. Facebook e Instagram localizaram páginas de anônimas de ataques a adversários políticos ligadas a Tércio Arnaud Tomaz, assessor especial da presidência e suposto integrante do gabinete do ódio (SOPRANA; ONOFRE; CAMPOS MELLO, 2020).

Em depoimento à CPMI das fake news, a deputada federal Joice Hasselmann, ex-aliada e atual desafeta do bolsonarismo, corroborou a tese de um ecossistema de comunicação digital em uma estrutura piramidal. No topo estariam a família Bolsonaro e assessores próximos, incluindo o gabinete do ódio. Uma vez definidos os alvos, começariam as publicações em massa nos perfis de políticos (família Bolsonaro, deputados e ministros bolsonaristas) e influenciadores (o filósofo autodidata Olavo de Carvalho e discípulos). Em seguida começaria o "movimento de manada": replicação e mimetização dos conteúdos por sites hiperpartidários, perfis anônimos e movimentos de extrema direita. Em redes como o Twitter, perfis robôs ajudariam 
com o crescimento artificial das pautas, por meio do impulsionamento de hashtags, por exemplo.

Os grupos públicos bolsonaristas no WhatsApp se situariam no nível inicial do movimento de manada, replicando conteúdos produzidos centralmente e, amparados pela criptografia da rede, publicando peças de teor mais agressivo que nas redes sociais abertas. De lá, a informação atinge a base da pirâmide via viralização, percolando em grupos particulares (de família, amigos, trabalho) e atingindo, potencialmente, uma vasta camada da população.

\section{Metodologia}

As características específicas da plataforma WhatsApp acarretam complexidades metodológicas e éticas para a pesquisa. A criptografia confere ao aplicativo um caráter opaco ao controle social. No caso dos grupos bolsonaristas, um complicador adicional é a recorrência de estratégias de expulsão de supostos opositores. Não raro circulam listas de "infiltrados" com a recomendação de que os administradores promovam varreduras constantes nos contatos para exclui-los.

Optou-se, assim, pela pesquisa encoberta, definida pela resolução 510/2016 do Conselho Nacional de Saúde (CNS). Trata-se de modalidade em que o pesquisador se junta aos grupos sem divulgar identidade ou objetivo da pesquisa. Não há publicação e distribuição dos termos da pesquisa e de seus procedimentos, o que impede que os integrantes optem pela participação livre e esclarecida. Segundo Chagas, Modesto e Magalhães (2019), a ausência do direito de não ser pesquisado é a principal controvérsia ética. Apesar disso, citando Padilha et al., os autores afirmam que o método "não deve ser rejeitado, visto que a coleta de dados por outras formas é inviável" (CHAGAS; MODESTO; MAGALHÃES, 2019, p. 2). Entende-se que é o caso aqui, inclusive em virtude de possíveis hostilidades ao pesquisador. Ressalte-se, porém que 1- o levantamento se deu apenas em grupos públicos, cujos links de acesso podem ser encontrados outros grupos semelhantes e em páginas de apoio a Bolsonaro na internet e 2- as precauções relativas à privacidade incluíram o não armazenamento de informações pessoais dos pesquisados, à exceção dos números telefônicos, cujo fornecimento a outros integrantes dos grupos não fere as políticas de uso do WhatsApp. -, preservaram-se todos os demais dados privados dos sujeitos pesquisados.

Em termos práticos, os dados foram coletados por meio de smartphone específico associado aos grupos. A amostra não probabilística por conveniência foi 
extraída de um universo de 30 grupos públicos de WhatsApp monitorados pelo pesquisador desde 2018. Para a seleção da amostra, foram excluídos grupos com nomes não relacionados ao bolsonarismo (Senta a Púa, Stellacruz etc.), ligados à direita em geral (direita Brasil etc.), regionais (direita Goiás, Paulista etc.), veículos informativos, mesmo que alinhados ao bolsonarismo, grupos ex-bolsonaristas (apoio a lava-jato, nacionalismo) e de pautas setoriais (limpeza no Judiciário). Foram mantidos 18 grupos cujos nomes expressassem, presentemente, apoio explícito ao presidente Bolsonaro, fosse com seu nome, apelidos (mito etc.), slogans por ele usados (pátria amada, Brasil; Brasil Acima de Tudo etc.), pautas caras a seu mandato, seu projeto de partido (Aliança pelo Brasil etc.) ou figuras satélite do bolsonarismo (Michelle Bolsonaro).

Após o ingresso nos grupos, ajustou-se a metodologia de Garimella e Tyson (2018), que consiste no monitoramento manual de dados, a importação da amostra para planilhas de análise e a caracterização dos atributos essenciais da comunicação. Passou-se à contagem das mensagens enviadas nos grupos selecionados, entre os dias 6 e 8 de julho de 2020, perfazendo um período de coleta de 48 horas. Obteve-se um total de 3.211 mensagens, média de 178 por grupo (n. máx. $=504, \mathrm{n}$. mín. = 8). Em comparação com outros dois momentos de coleta (RATIER, 2020a, 2020b), observa-se diminuição na atividade dos grupos: em junho de 2019 , foram em média 236 mensagens trocadas diariamente. Em fevereiro de 2020, 140 mensagens, e em julho de 2020, 89.

O intervalo coincide com a progressiva deterioração das condições de governabilidade de Jair Bolsonaro. O front da comunicação foi atingido com revelações da CPMI das fake news e pelo inquérito do Supremo Tribunal Federal sobre o mesmo tema. Em junho de 2020, youtubers bolsonaristas teriam apagado 3.463 vídeos de seus perfis (ALVES, 2020). A retirada sucede operações de busca e apreensão e a prisão de um blogueiro aliado. Também ocorreu no período a prisão de Fabrício Queiroz, amigo pessoal do presidente há três décadas, ex-assessor parlamentar do então deputado estadual Flávio Bolsonaro, acusado de ligações com milícias e de liderar um esquema de "rachadinhas" na Assembleia Legislativa do Rio de Janeiro. A detenção de Queiroz levou à diminuição de manifestações públicas de Jair Bolsonaro e de um abrandamento de tom em seu perfil no Twitter.

O período selecionado para a amostra, por sua vez, registrou no noticiário relativo a Bolsonaro a soltura do blogueiro simpatizante Oswaldo Eustáquio Filho e de dois apoiadores que fizeram atos contra o ministro do STF, Alexandre de Moraes. Na economia, queda na arrecadação federal pelo $5^{\circ}$ mês consecutivo. No meio 
ambiente, um pedido de combate ao desmatamento de 36 grandes companhias ao vice-presidente Hamilton Mourão, presidente do Conselho Nacional da Amazônia Legal. As notícias sobre a pandemia de covid-19 davam conta de um aumento nos óbitos em casa e em vias públicas, fato atribuído a falhas no enfrentamento ao coronavírus. $\mathrm{O}$ próprio presidente, após minimizar a doença, acabou testando positivo no dia 8 de julho, iniciando no próprio momento do anúncio apologia ao medicamento hidroxicloroquina, sem eficiência comprovada cientificamente no tratamento dos sintomas.

Tabuladas as interações entre os grupos, destacou-se o grupo cujo número de mensagens mais se aproximasse da média (179 interações). As conversas foram enviadas para tabulação pela opção "exportar conversas sem mídia" do aplicativo, resultando em um arquivo de texto convertido para o software Excel. As peças sonoras, visuais ou audiovisuais foram examinadas posteriormente uma a uma pelo pesquisador para os procedimentos de categorização do conteúdo.

\section{Apresentação dos resultados}

No período da coleta de dados, o grupo contava com 201 integrantes, excluindo o pesquisador. Foi criado em 05 de dezembro de 2018 por um número telefônico registrado nos Estados Unidos, embora a descrição do grupo informe que o "criador e administrador" é um homem supostamente de João Pessoa, Paraíba. O grupo conta com 6 administradores. No período de análise, dois integrantes abandonaram o grupo, sendo excluídas as duas sinalizações de saída do total de mensagens $(\mathrm{n}=177)$.

Quanto aos participantes, verificaram-se tendências expressas, em estudo anterior (RATIER, 2020b), de que: 1- a grande maioria dos usuários não interage no grupo; 2- os fluxos comunicativos estão concentrados em uma "elite falante" de integrantes. Ao longo das 48 horas analisadas, apenas $23 \%$ dos integrantes ( $n=47)$ postaram algum conteúdo. A atividade de postagem, por sua vez, também se encontra desigualmente distribuída. Apenas 4\% dos usuários (n=9) são responsáveis por $\mathbf{5 0 \%}$ das mensagens enviadas, sendo que $17 \%$ do conteúdo é produzido ou compartilhado por apenas dois números de telefone. Ressalte-se, ainda, que a "elite administrativa" pouco postou: apenas 3 das 179 mensagens ( $1,6 \%$ do total) partiram de 2 dos 6 celulares cadastrados como responsáveis pelo grupo (Tabela 1). 
Tabela 1 - Usuários e mensagens enviadas

\begin{tabular}{c|c|c|c}
\hline Número de usuários & $\%$ do total de usuários & Número de mensagens & $\%$ do total de mensagens \\
\hline 154 & $77 \%$ & 0 & $0 \%$ \\
47 & $23 \%$ & 177 & $100 \%$ \\
9 & $4 \%$ & 90 & $50 \%$ \\
2 & $1 \%$ & 31 & $17 \%$ \\
\hline
\end{tabular}

Fonte: elaboração própria.

Também há congruência com Ratier (2020b) quanto à natureza das mensagens: $90 \%$ delas $(\mathbf{n}=158)$ foram produzidas por terceiros, sendo $41 \%$ encaminhadas $(\mathrm{n}=72)$ e $49 \%$ copiadas $^{1}(\mathrm{n}=86)$. Apenas $7 \%$ das mensagens podem ser consideradas como autorais $(n=12)$, sendo basicamente emojis $(n=2)$ e textos de resposta $(\mathrm{n}=10)$. Muito curtos (média de 53 caracteres por resposta, $20 \%$ do limite das postagens no microblog Twitter), apresentavam tom de concordância a alguma postagem anterior. Não foi possível identificar a natureza de $4 \%$ das mensagens.

Em termos de mídia, predomínio dos recursos audiovisuais: $55 \%(n=97)$, sendo $32 \%$ vídeos $(n=56), 20 \%$ imagens $(n=35)$ e $3 \%$ áudios $(n=6)$. Postagens com links externos são $28 \%(n=50)$, textos, $13 \%(n=23)$ e emojis, $4 \%(n=7)$. Ao todo, $\mathbf{5 9 \%}$ das postagens são nativas do WhatsApp (n=106), o que significa alta acessibilidade para planos de internet móvel populares que possibilitam navegação ilimitada no aplicativo, mas não em recursos fora dele. Links externos $(41 \%, n=71)$, por sua vez, apontam sobretudo para sites hiperpartidários, de apoio explícito a Bolsonaro. Eles são 58\% do universo de links externos ( $n=41)$, enquanto a mídia profissional representa apenas $7 \%(\mathrm{n}=5)$. O restante dos links aponta para redes sociais como o YouTube $(24 \%, \mathrm{n}=17)$, Facebook $(7 \%, \mathrm{n}=5)$ e Twitter $(3 \%, \mathrm{n}=2)$. Novamente, as ordens de grandeza são semelhantes às encontradas em estudo anterior.

A análise de conteúdo se deu na mesma amostra entre os dias 10 e 14 de junho. Das 177 mensagens originais, foram consideradas 174 cujos links e mídias se encontravam ativos no momento da análise.

Pode-se identificar o gênero discursivo em 163 postagens. Seguindo Chaparro (1998), operou-se a distinção basal dos gêneros jornalísticos, a separação entre informação e opinião - reconhecendo-se, para tanto, o aspecto proeminente em cada uma das postagens. Houve predominância do gênero opinativo em $60 \%$ das postagens ( $\mathrm{n}=98)$, sempre favoráveis a Bolsonaro. O gênero informativo esteve presente em $32 \%$ postagens $(n=52)$, o publicitário em $5 \%(n=8)$ e outros em 
$3 \%(\mathrm{n}=5)$, porcentagens semelhantes, uma vez mais, a estudo anterior (RATIER, 2020a).

Entre os opinativos, destacam-se os vídeos de dois tipos. Os que remetem a links do YouTube são mais longos, entre 13 minutos e 2 horas de duração, e costumam recorrer à estrutura opinativa clássica: um comentarista em plano americano, falando diante de um cenário caseiro ou em chroma key (fundo virtual), abordando algum assunto polêmico ou realizando um "giro de notícias" opinativo. Já os vídeos nativos para WhatsApp são mais curtos (máximo de 8 minutos) e priorizam edições de trechos maiores - discursos de políticos, testemunhos de populares, excertos de programas de TV ou vídeos em redes sociais. Tendem a ser discursivamente mais agressivos, confirmando a vocação da plataforma para peças mais radicais.

As postagens informativas são sobretudo links de veículos informativos hiperpartidários, com pauta de defesa do presidente Bolsonaro (Goiás 365, Tudo OK Notícias, Duna Press etc.). As reportagens não trazem apuração própria e são, em geral, de fonte única e oficial: reaproveitamento de falas do presidente em postagens na internet, releases de ministérios do governo, do site gov.br ou da estatal Agência Brasil, cópias de veículos como O Antagonista, CNN e Jerusalem Post. A maioria dos textos não é assinada. As postagens classificadas como publicitárias, por sua vez, são vídeos com ações do governo na pavimentação de estradas e entrega de equipamentos às polícias, seguindo a estrutura padrão de narração em off, lettering (inserções de texto no vídeo) e imagens de cobertura.

\section{Padrões de conteúdo, tema e estratégias discursivas}

Em sua pesquisa online em grupos públicos de WhatsApp durante o período eleitoral em 2018, Cesarino (2019a) apresenta funções metalinguísticas básicas que, segundo a autora, "cobrem praticamente todo o conteúdo coletado" nas redes bolsonaristas: 1- fronteira antagonística amigo-inimigo; 2- equivalência líder-povo; 3- mobilização permanente através de ameaça e crise; 4- deslegitimação de instituições para a produção de um canal midiático exclusivo ${ }^{2}$. Considerou-se que seriam boas balizas para a classificação do conteúdo e a indicação de eventuais padrões de recorrência.

Com efeito, $79 \%$ das postagens $(n=138)$ apresentava uma ou mais das quatro funções básicas apresentadas pela autora. Desse total, 28\% (n=49) apresentaram duas funções e 6\% (n=11), três funções (Gráfico 1): 
Gráfico 1 - padrões de estruturação de conteúdo (respostas múltiplas)

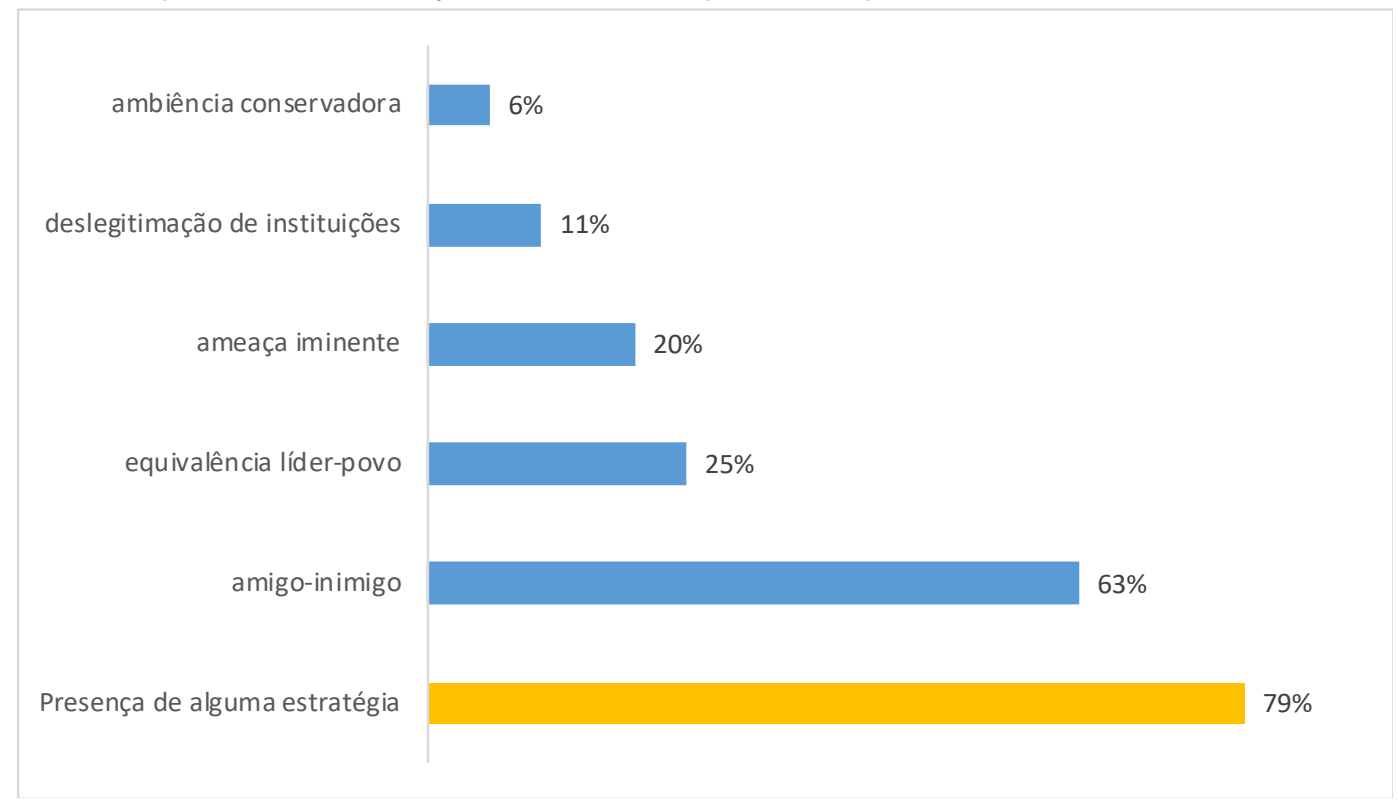

Fonte: elaboração própria.

Entre as estratégias analisadas, destaca-se a fronteira antagonística amigo-inimigo, com 63\% ( $\mathrm{n}=109$ ). Em seguida a equivalência líder-povo, com $25 \%$ ( $\mathrm{n}=43$ ), mobilização permanente através de ameaça e crise $20 \%(\mathrm{n}=35)$ e deslegitimação de instituições para a produção de um canal midiático exclusivo, com $11 \%$ ( $\mathrm{n}=19$ ). Identificou-se, ainda, um quinto padrão de produção de conteúdo que denominamos ambiência conservadora, com 6\% ( $\mathrm{n}=10)$. São sobretudo postagens de cunho religioso (leituras de evangelho e sua exegese, músicas evangélicas etc.), que sugerem aspecto relevante a compor identidade conservadora e ligada a valores tradicionais ambicionada por Bolsonaro.

Quanto aos temas, predominância das postagens que orbitam em torno de temas da atualidade (covid-19, 31\%, n=54, em geral com críticas à oposição e elogios ao governo) e do líder (Bolsonaro, 25\%, n=44). A seguir é possível identificar um bloco de "neoinimigos" (20\%, $\mathrm{n}=34$ ), representados pelos outros poderes ( $\mathrm{STF}$, congresso) e demais níveis de governo (governadores, prefeitos) e mesmo o "fogo amigo" no executivo (ministros e militares que não estariam apoiando Bolsonaro o suficiente). Os "velhos inimigos" (PT e Lula, esquerda, Venezuela e Maduro) perfazem 11\% ( $\mathrm{n}=19)$. Outros antagonismos (Globo, meio ambiente, China), 8\% ( $\mathrm{n}=13)$, e as menções de cunho religioso, $5 \%(\mathrm{n}=8)$ (Gráfico 2$)$. 
Gráfico 2 - Temas das postagens (respostas múltiplas)

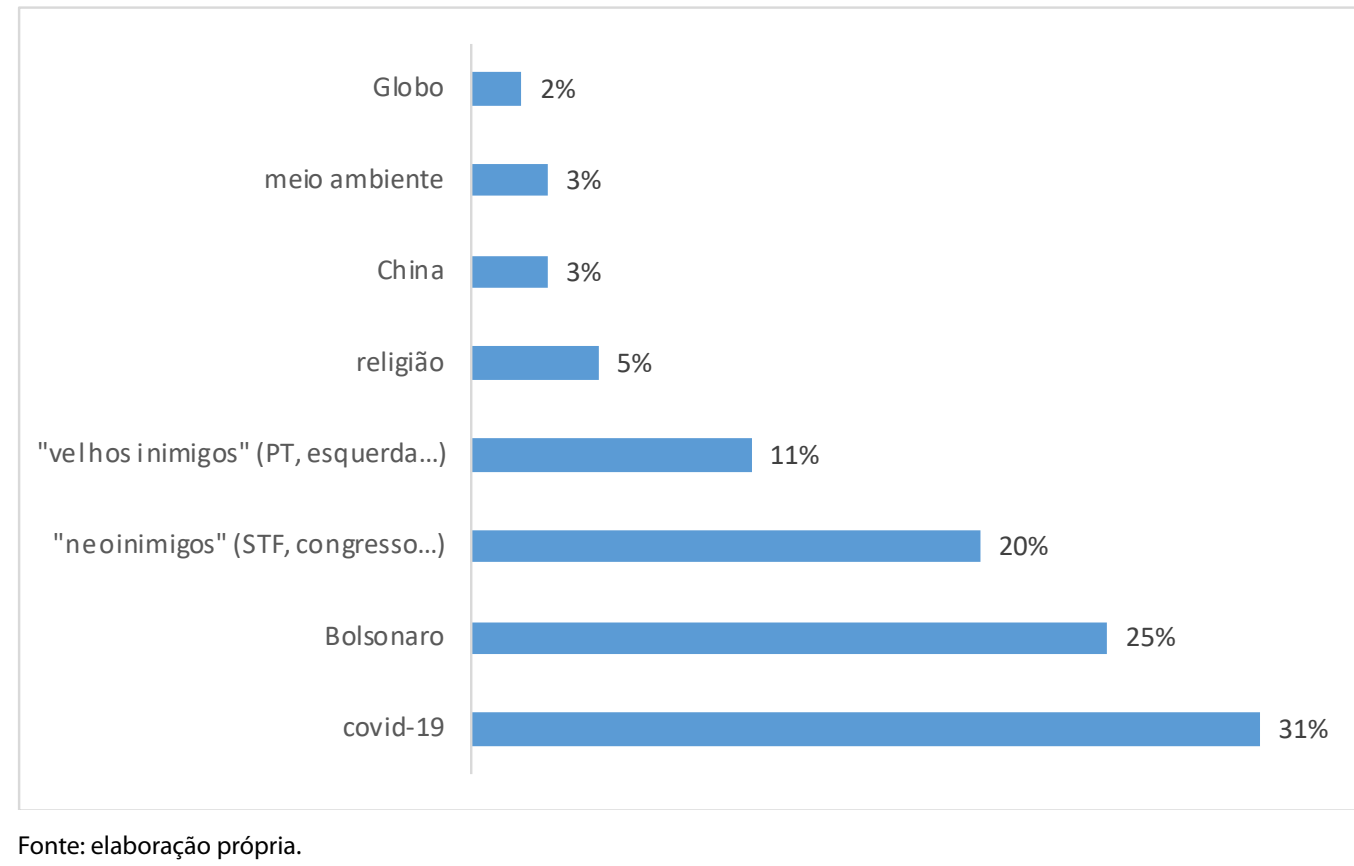

Buscou-se, ainda, mapear as principais estratégias discursivas, relacionadas à forma das postagens. Pode-se apontar três vetores principais. Um primeiro, voltado à descontextualização $(45 \%, \mathrm{n}=78)$, reúne técnicas como edição enviesada, editorialização, falsa equivalência, inversão de acusação, indeterminação de agentes, caricaturização e metáforas. Um segundo, que poderíamos chamar de formas alternativas de veridição (44\%, $\mathrm{n}=76$ ), abarca, conforme Cesarino (2021), estratégias de questionamento ao paradigma jornalístico da objetividade: informações falsas, teorias da conspiração e experiências imediatas - notadamente, vídeos testemunhais. Um terceiro, o do apelo à emoção $(42 \%, \mathrm{n}=73)$, compreende vitimização, chamado à ação da militância, hipérboles e desumanização. Ressalte-se o uso dos três recursos em nível muito superior a outras estratégias discursivas mais clássicas como a linguagem de notícia ( $21 \%, \mathrm{n}=36$, em geral de fonte copiada da grande mídia ou de fonte oficial do governo), humor $(3 \%, \mathrm{n}=6)$, propaganda $(3 \%, \mathrm{n}=5)$ e argumentação $(2 \%, \mathrm{n}=4)$ (Gráfico 3): 
Gráfico 3 - Padrões de estratégias discursivas (respostas múltiplas)

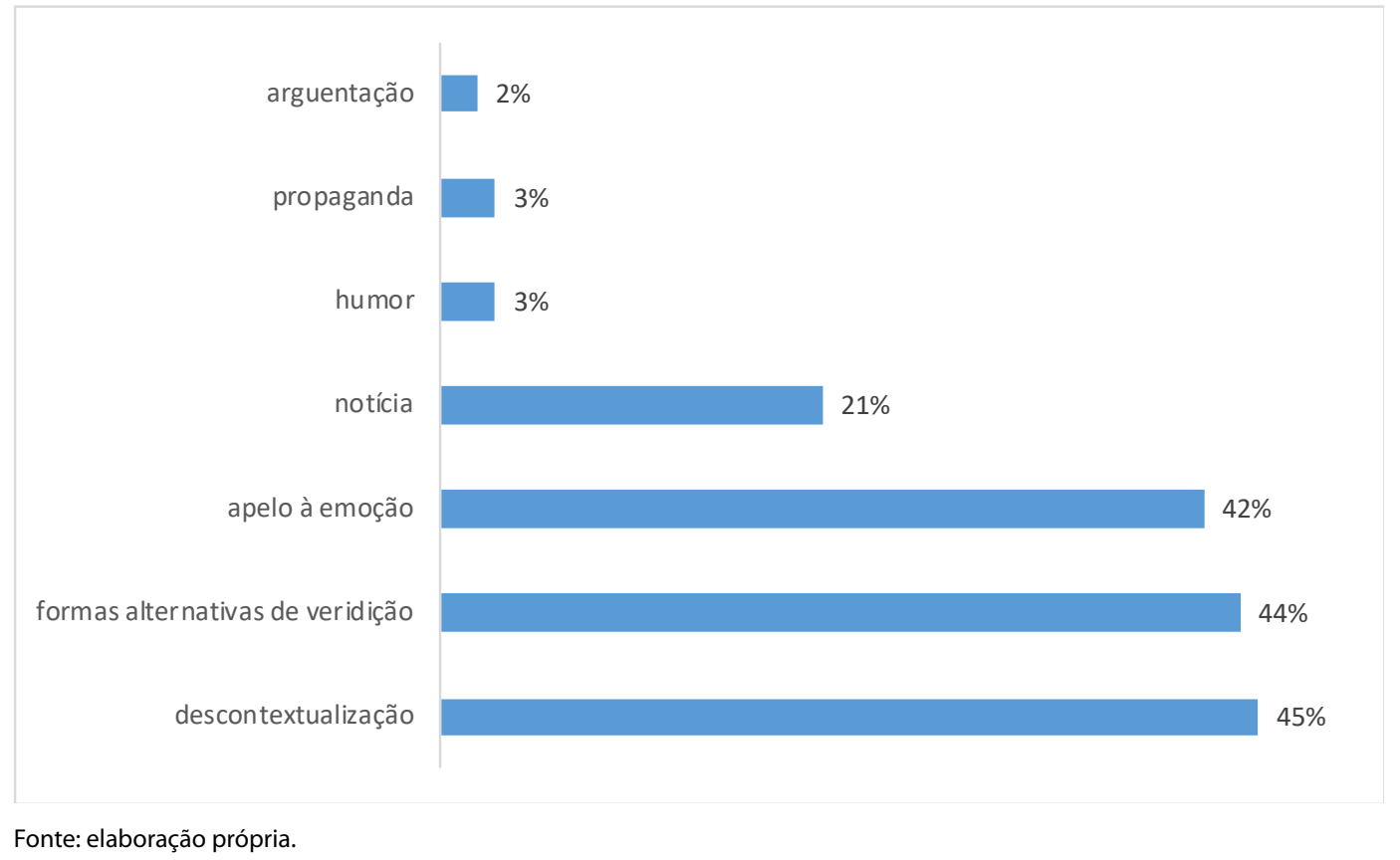

\section{Discussão dos resultados}

Defende-se que a materialização de uma "pedagogia da ameaça" nos grupos bolsonaristas se alicerça em um conjunto de padrões de comunicação, sobressaindo-se três: 1- binômio amigo-inimigo, 2- apelo à emoção e 3- estratégias de desinformação.

O gênero preferencial do WhatsApp bolsonarista é o opinativo - explicito ou disfarçado pelo formato de "giro de notícias", ainda que o conteúdo seja evidentemente editorializado. Sua roupagem usual são os vídeos em que um comentarista, posicionado diante de um cenário caseiro ou fundo do tipo chroma key (são frequentes montagens virtuais com estantes de livros), exprime pontos de vista sobre um ou mais assuntos. O polemismo é a marca, com uso extensivo do ad hominem para identificar adversários e defender o presidente. O youtuber bolsonarista Mauro Fagundes chama Sergio Moro, ex-aliado e atual desafeto dos bolsonaristas, de "afeminadozinho", "abaitolado" que "botou os mamilos de fora" e que, na realidade, seria um "agente do PCC". Os vídeos nativos do aplicativo tendem a ser mais curtos e mais virulentos. Em um deles, homem não identificado, com maquiagem de 
palhaço e camisa do exército, critica com palavrões, linguagem bélica e expressões ameaçadoras os generais que, supostamente, não defendem Bolsonaro. "Ninguém tem obrigação de ficar babando o ovo [dos generais]. Tem mais é que sacanear para eles caírem na real".

O binarismo amigo-inimigo aparece com frequência nos memes que circulam pelo grupo. Em seu estudo sobre o WhatsApp bolsonarista, Cesarino (2019a, 2019b) recorre à definição "técnica" de Laclau (2013) para sublinhar os dois traços fundantes do populismo: a equivalência entre líder e povo e a demarcação evidente de aliados e inimigos. Esses últimos, mais que adversários, são grupos que, ao se oporem ao líder, põem em risco a própria existência social (uma vez que o líder é o povo), devendo por isso ser eliminados. A referência incontornável é a obra política de Carl Schmitt (2009), cientista político iliberal para quem a "essência" do político é a organização coletiva de um grupo contra inimigos internos e externos. A guerra, manifestação extrema da inimizade, é o pressuposto existente como possibilidade sempre real. Estratégias discursivas desumanizadoras são peça chave na construção da imagem do inimigo político, pois ele:

É precisamente o outro, o desconhecido e, para sua essência, basta que ele seja, em um sentido especialmente intenso, existencialmente algo diferente e desconhecido, de modo que, em caso extremo, sejam possível conflitos com ele, os quais não podem ser decididos nem através de uma normalização geral empreendida antecipadamente, nem através da sentença de um terceiro "não envolvido" e, destarte, "imparcial” (SCHMITT, 2009, p. 28).

Concorda-se com Cesarino (2019a, 2019b) que a equivalência líder-povo e a antítese amigo-inimigo são características evidentes na memética bolsonarista. Se a lista de inimigos abarca hoje virtualmente toda a institucionalidade, a tripartição de poderes e os sistemas de freios e contrapesos constituintes da democracia moderna, a esquerda segue sendo o alvo tradicional.

Nos dois exemplos a seguir, texto e arte sugerem, por meio de uma cadeia de associação, a correspondência entre esquerda e malfeitos. $\mathrm{O}$ apelo à emoção é evidente na primeira imagem, com a equiparação de Lula a autores de crimes violentos de forte impacto na opinião pública. Descontextualizado, o texto traz a sugestão de que todos teriam sido contemplados com a impunidade judicial (Figura 1). No segundo, o significante "PT" é alargado - à moda do significado elástico de "comunismo", que conforme Adorno (2020) perde sua concretude e adquire um caráter místico e abstrato -, de modo a abarcar a centro-direita do ex-presidente Michel Temer (MDB) e do deputado federal Aécio Neves (PSDB). Passa, na prática, a significar todo o sistema político (a "velha política") e seus defensores. Num 
entorno ameaçador, a complexidade da escolha se reduz à opção entre bem e mal (Figura 2). O tuíte de Allan dos Santos (Figura 3) estende o malefício aos demais poderes da institucionalidade democrática (STF, Congresso). A ameaça iminente justifica um chamado enfático à ação. O senso de urgência é evidenciado pelo uso de letras maiúsculas nas expressões "precisa", "efetivo" e "mais do nunca":

Figura 1 - Cadeia de associações

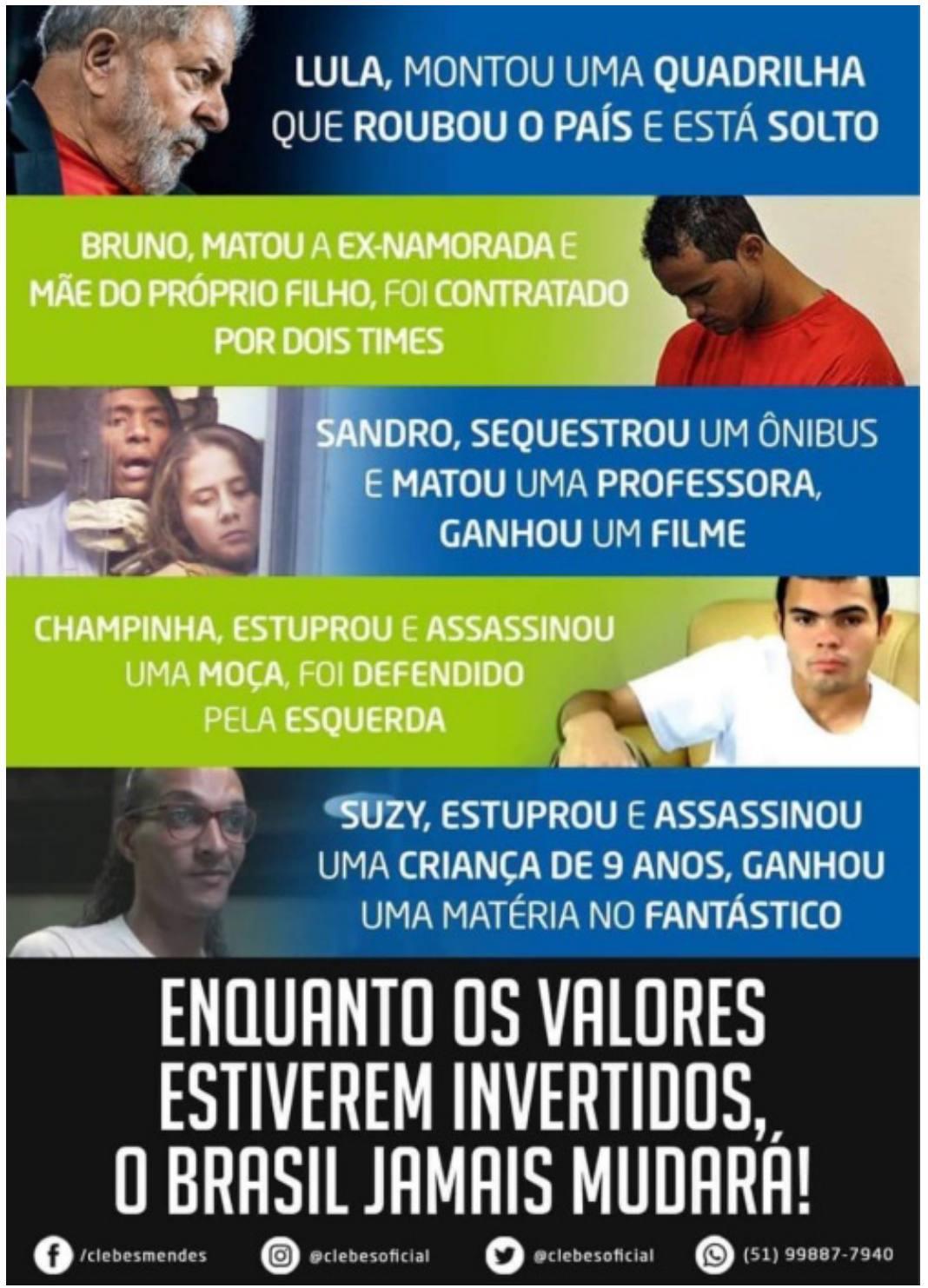

Fonte: grupos de WhatsApp pró-Bolsonaro. 
Figura 2 - Oposição amigo-inimigo

Fomos dormir e entregamos as chaves da casa ao PT. Quando acordamos, 0 Brasil tinha 400 mil ONGs, 17 mil sindicatos, 149 estatais, dívida pública triplicada, serviços públicos básicos falidos e os piores casos de corrupção da história. Mas tinha coisa pior: pessoas defendendo esse partido.

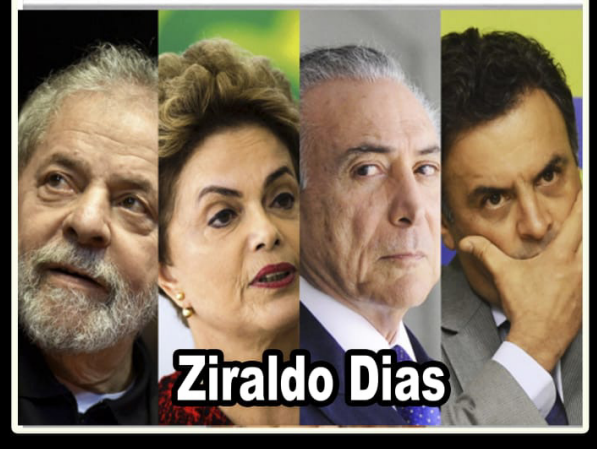

Fonte: grupos de WhatsApp pró-Bolsonaro.
Figura 3 - Plasticidade da categoria "inimigo"

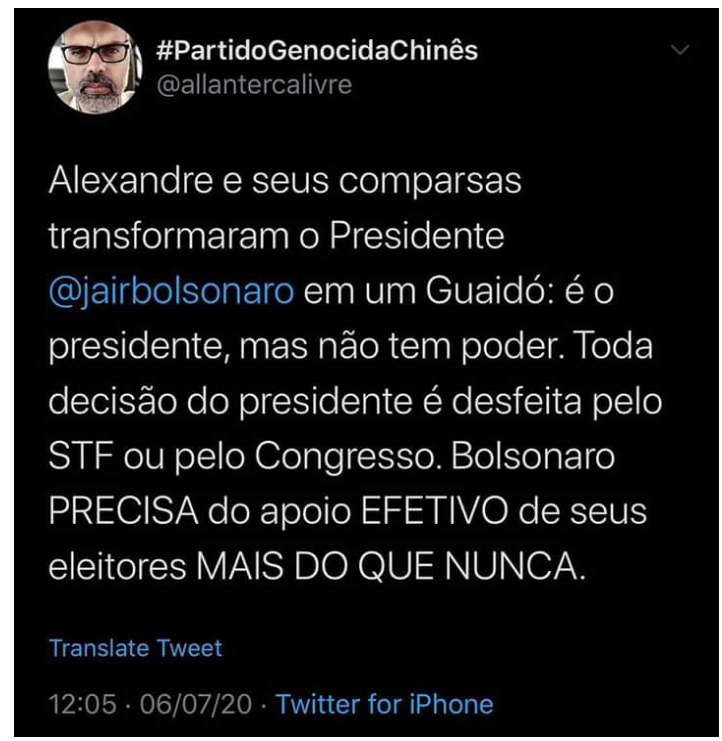

Fonte: grupos de WhatsApp pró-Bolsonaro.

A equivalência líder-povo, por sua vez, procura equiparar uma espécie de sujeito coletivo da nação ao caudilho ressaltando aspectos do culto à personalidade de Bolsonaro (simplicidade, conservadorismo, disciplina, religiosidade). Construída pela síntese entre imagem e título telegráfico, o meme não assinado sugere humildade e fé. $\mathrm{O}$ apelo à emoção e o reforço ao binarismo amigo-inimigo se ampliam no texto encaminhado que acompanha o meme: "ajoelhado em frente ao Santíssimo Sacramento, buscando forças para combater os comunistas e outros inimigos da Igreja e do Brasil. Que Jesus e Maria o abençoe [sic], grande presidente!" (Figura 4). Valores vagos e carregados de emoção - homem de família, patriota, honesto e antiabortista - são evocados no meme ilustrado em verde amarelo e com a bandeira do Brasil, opções recorrentes na estética bolsonarista. Mesmo que o nome do presidente não esteja explicitamente evocado, a associação pelo contexto é evidente (Figura 5). A gramática simples baseada em oposições do tipo certo-errado (amarelo versus vermelho, bandeira do Brasil versus bandeira vermelha, semblante alegre versus cara fechada, torcida pela cloroquina versus torcida pelo coronavírus) é a base para a charge sobre a epidemia da covid-19 (Figura 6): 
Figura 4 - Equivalência líder-povo

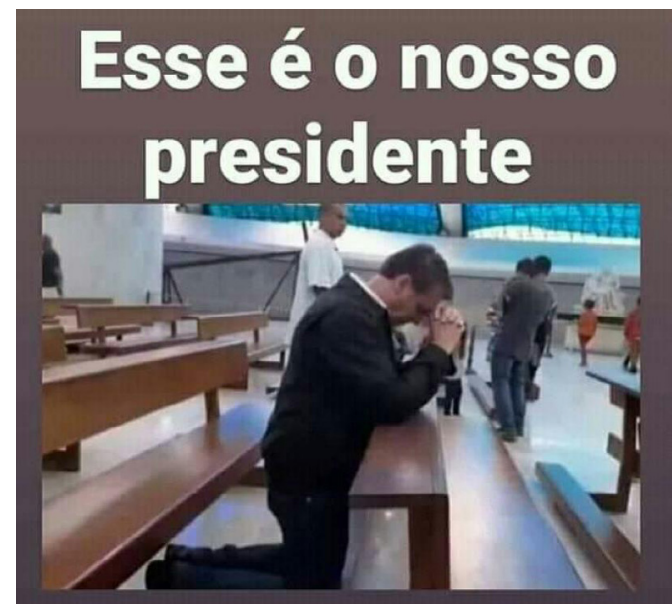

Fonte: grupos de WhatsApp pró-Bolsonaro.
Figura 5 - Valores emocionais vagos

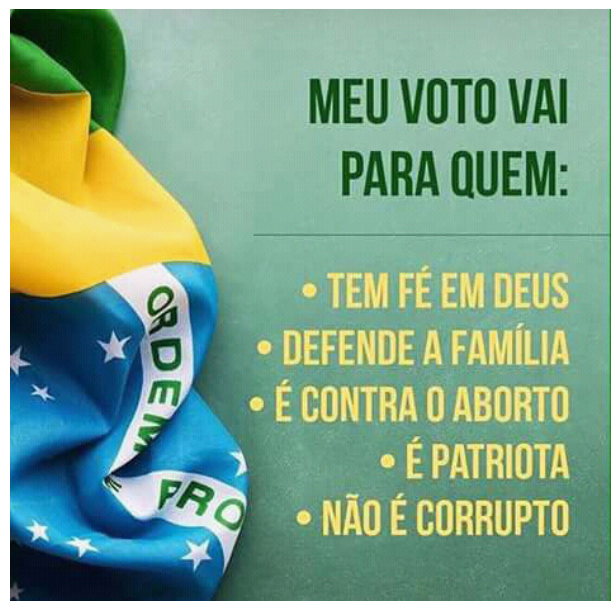

Fonte: grupos de WhatsApp pró-Bolsonaro.

Figura 6 - Gramática da oposição simples

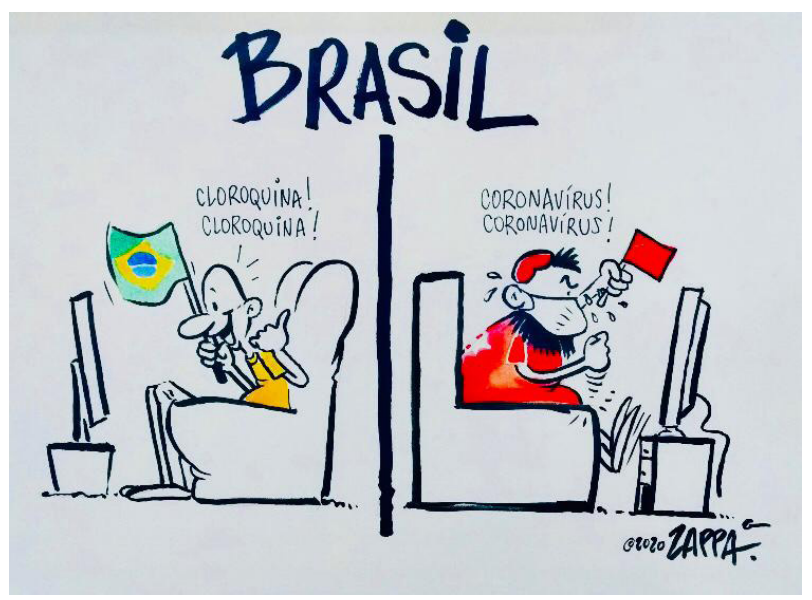

Fonte: grupos de WhatsApp pró-Bolsonaro.

O enquadramento emocional e a manipulação do medo são evidenciados por Serelle e Soares (2019), Chagas, Modesto e Magalhães (2019) como estratégias basais na comunicação digital da chamada nova direita. Não soa descabido falar em reavivamento de técnicas de psicologia de massa do fascismo (REICH, 1988) ou do radicalismo de direita (ADORNO, 2020). Citando Hitler, Reich (1988, p. 48) afirma que o próprio ditador nazista acentua a tática de, nos comícios diante das massas, 
abrir mão da argumentação, manejando de forma efetiva as emoções e apontando apenas o "grandioso objetivo final". Em Mein Kampf, o ditador nazista afirma que que os pensamentos e ações do povo "são determinados muito mais pela emoção e sentimento do que pelo raciocínio" e guiados por uma espécie de binarismo avaliativo: "não há muitas nuanças; há sempre um positivo e um negativo; amor ou ódio, certo ou errado, verdade ou mentira, e nunca situações intermediárias ou parciais" (REICH, 1988, p. 61). Adorno também vê um esquema do tipo estímulo-resposta na latência do fascismo na Alemanha do final dos anos 1960. Afirma que todas as manifestações ideológicas do radicalismo de direita estão marcadas pela necessidade de convocar o que chama de "personalidade autoritária" - estímulo de ressentimentos, medos, chamados à ordem e à disciplina -, estratégia capaz de "levar as audiências ao ponto de ebulição" (ADORNO, 2020, não paginado). Para Adorno, o estado de agitação permanente é tudo o que o fascismo poderia oferecer: o radicalismo de direita seria marcado por ausência de propostas e desejo de catástrofe, flertando de forma muito profunda com a psicose.

Por fim, uma parcela do binarismo amigo-inimigo é construída com base em informações fraudadas, falsas, distorcidas ou descontextualizadas - para Adorno (2020), esse último recurso é a principal técnica por meio da qual a verdade se põe a serviço da falsidade. $O$ texto que acompanha a imagem em branco e preto, suposta ganhadora do Prêmio Pulitzer, fala em um proprietário de terra, abençoado por um padre, morto por fuzilamento porque "se recusou a trabalhar para o regime de Fidel Castro". A ameaça "comunista” representada por Cuba e Venezuela - e, mais recentemente, Argentina, que "quis pagar o preço para ver o resultado de um governo esquerdista ligado ao Foro de São Paulo de novo", como diz uma das mensagens do período -, é frequente, costumeiramente inserida numa cadeia de equivalência com violência, ditadura, censura, pobreza e ineficiência estatal. No exemplo em tela, serviço de checagem de fatos indica que se trata de uma fake news com versões em português de Portugal e em espanhol. A fotografia de Andrew Lopez é efetivamente vencedora do Pulitzer, mas retrata um cabo do exército do regime ditatorial de Fulgencio Batista, derrubado pela Revolução Cubana (Figura 7). Foi executado após ser considerado culpado por um tribunal militar por crime de guerra (MORAES, 2019). Não há registro de que a ordem tenha partido de Ernesto "Che" Guevara. Outra postagem do período desmentida (MATSUKI, 2020) é “URGENTE! TRIBUNAL CONSTITUCIONAL MILITAR!”, que fala na iminência da assinatura presidencial para um decreto que cria "um novo tribunal ACIMA DO STF, para processar e julgar TODOS os bandidos e criminosos que estão nos 
Poderes da República”. A postagem também termina com uma exortação à militância digital: "Gostou da notícia!? Então compartilhe ao máximo! E vamos subir com urgência a hashtag: \#TribunalConstitucionalMilitarJá!!!”.

Figura 7 - Desinformação

Essa foto ganhou o Pulitzer. Um padre dando a última bênção à um camponês cubano, proprietário de terra, que se recusou a trabalhar para o regime de Fidel Castro, e que foi condenado por "Che", sem direito à defesa, a morrer por fuzilamento. Você nunca verá essa foto na camiseta de um comunista ptista ou de um partido de esquerda .

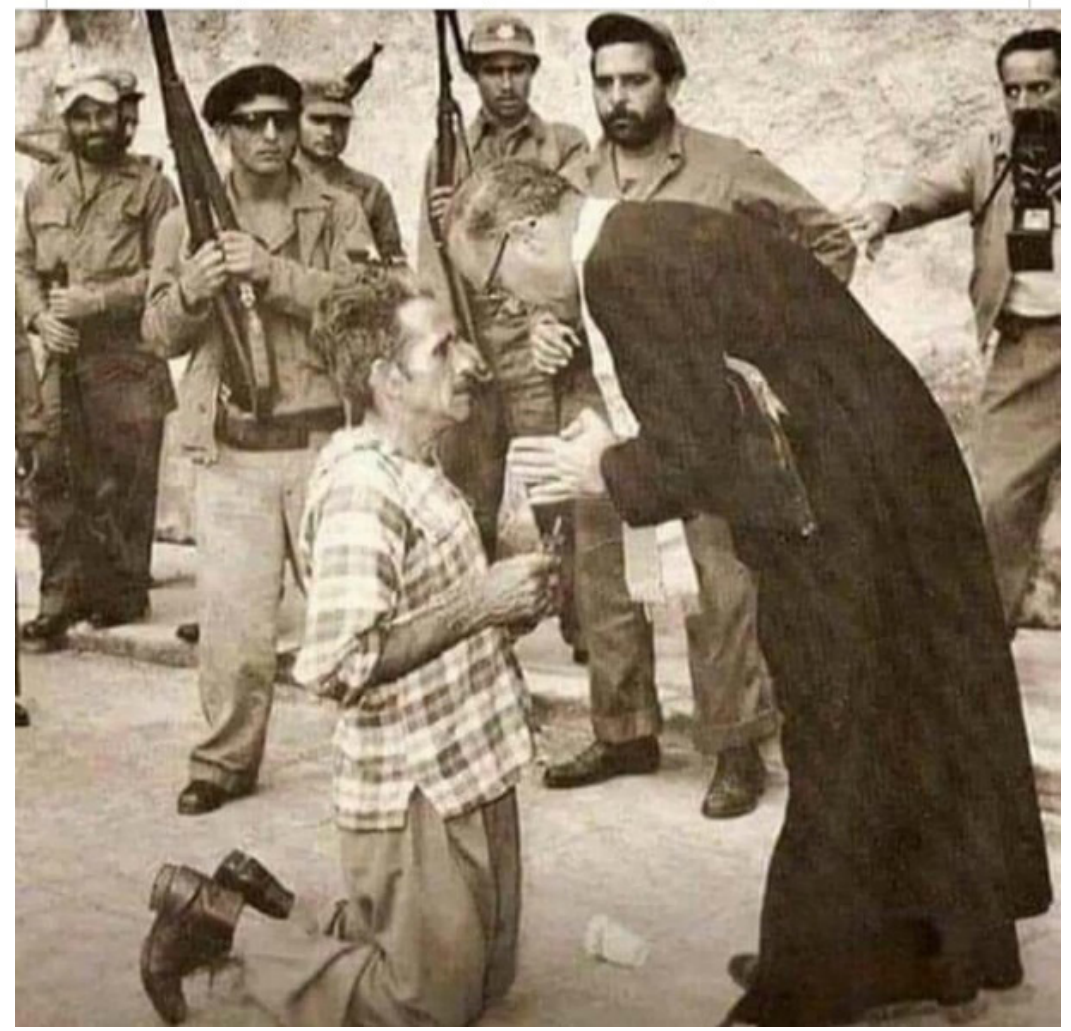

Fonte: grupos de WhatsApp pró-Bolsonaro.

Concordando com Pinheiro e Brito (2014) e conferindo à desinformação um sentido amplo - informação de baixo valor cultural ou utilidade para a participação no processo político e a tomada de decisões cotidianas -, tem-se que grande 
parte do conteúdo do WhatsApp bolsonarista pode ser encaixado nessa categoria. Incluem-se aí diferentes estratégias de descontextualização (informações falsas, edições enviesadas, produções ofensivas etc.) e o que se pode chamar de formas alternativas de veridição. Segundo Cesarino (2020, no prelo), tratam-se de epistemologias populares que tendem a funcionar como estratégias de legitimação de um determinado relato.

Tal contexto se torna possível diante da crise do sistema de peritos (universidade, jornalismo, ciência) e de um ecossistema midiático altamente poluído. Cesarino (2020, no prelo) define a pós-verdade como uma situação de desordem informacional, enquanto Romero-Rodriguez, De-Casas e Pedreira (2018) criam o neologismo infoxicação - junção de informação e intoxicação - para designar o consumo indiscriminado de informação de baixa qualidade. Para os autores, não se trata de conjuntura episódica, mas de "situação estrutural" das mídias na contemporaneidade:

Nace así la era de la "infoxicación" em la que se le da a la audiencia el contenido que esta desea - generalmente de infoentretenimiento - con el fin de asegurar cuotas de publicidad, a la vez que los propios receptores son incapaces de realizar un correcto filtrado de las informaciones, aceptando como ciertas aquellas que incluso son contrarias a otras que ya han aceptado como verdadeiras. Parece entonces que hemos llegado a comprender que la desinformación es uma situación estructural del ecosistema mediático y que las audiencias, paradójicamente, emergen como víctimas propiciatorias de este fenómeno ${ }^{3}$ (ROMERO-RODRIGUEZ; DE-CASAS; PEDREIRA, 2018, p. 74-75).

Destacam-se as teorias da conspiração. Em vídeo nativo do aplicativo, comentarista sugere que a China, a quem o governador João Doria estaria "entregando São Paulo", criou um "vírus muito letal para o resto do mundo" com um "braço comunista” - a Organização Mundial da Saúde (OMS). Em outro vídeo nativo, narrador não identificado compara a Covid-19 à dominação nazista. Afirma que o "sonho encantado dos comunistas" do Brasil era implantar o regime. "Para isso, precisa antes empobrecer a população para que ela venha comer aos pés dos governantes". Ambas a produções contêm forte apelo à emoção. O vídeo sobre a China tem música de suspense e tela inicial de alerta; o do nazismo, montagens e imagens fortes do holocausto.

As experiências imediatas também se encaixam nessa categoria. Em áudio atribuído a Alexandre Garcia, o jornalista ex-TV Globo e neoconvertido ao bolsonarismo lamenta a "politização da hidroxicloroquina": "Eu, como marido de médica, recebo informação dos médicos. Em Brasília no mínimo 130 médicos estão aplicando a hidroxicloroquina. Ouço todos os dias depoimento de gente que teve 
uma gripezinha graças à hidroxicloroquina [...]. As pessoas não estão mais indo na conversa de gente que vive de semear o pânico". O lettering que acompanha o áudio testemunhal ("O louco estava certo", "a mídia te manipulou e você acreditou”) aposta na deslegitimação da mídia, estratégia que vai em par com as formas alternativas de veridição.

\section{Conclusões}

No deberíamos subestimar estos movimentos por su ínfimo nível intelectual ni por su falta de teorización. Sería uma enorme falta de visión política pensar que por eso no van a tener éxito. Lo característico de estos movimentos es más bien um extraordinária perfección de los médios, y concretamente em primer lugar los médios propagandísticos em el sentido más amplio, combinada em semejante perfección de las técnicas y los médios, mientras que se escamotea de passo el fin que realmente se persigue para la sociedade em general ${ }^{4}$ (ADORNO, 2020, não paginado).

Mesmo instigado pela curiosidade que anima a pesquisa, acompanhar um grupo público de apoiadores do presidente Jair Bolsonaro é uma atividade penosa. Minha experiência pessoal é de repulsa: o smartphone exclusivo em que monitoro os grupos fica desligado exceto em momentos de ida a campo, sempre psicologicamente penosos. É de se imaginar o que uma instância de socialização opaca ao controle social, de baixa confiabilidade informativa, centrada no emissor, com pedagogia e gramática reforçadoras de um imaginário de ameaça permanente, possa acarretar às formas de ser, agir e pensar de uma relevante camada da população. A experiência no WhatsApp bolsonarista e a vivência de sua pedagogia da ameaça reconvocam termos e estratégias que pareciam superados tanto no campo da socialização quanto no da comunicação. É possível falar, por exemplo, em manipulação ou socialização ideologizada, no sentido de ideologia proposto por Thompson (1995): mensagens que reforçam estruturas de dominação, hierarquias e relações de poder. Ainda que sejam necessários estudos de recepção para que se entenda com maior clareza os significados que as audiências constroem a partir da mediação do ecossistema midiático bolsonarista, o sucesso eleitoral e a resiliência de sua base de apoio, a despeito de uma administração claudicante, são indícios da eficácia da produção de conteúdos.

É de se pensar sobretudo na manipulação fundamental operada pelo bolsonarismo. Com a estratégia de construção de um canal midiático exclusivo, simula-se um ambiente informativo, de troca de ideias e, por que não, de democracia direta, 
uma vez que existe a ilusão do contato direto, via tecnologia, do militante com o líder (CESARINO, 2019b). Entretanto, o que existe concretamente, mais do que as já conhecidas "bolhas semânticas" geradas pela algoritmização das redes sociais, é a instrumentalização de uma mídia pela propaganda - agravante: seu caráter tóxico. O binarismo amigo-inimigo cria indivíduos e grupos a serem eliminados. Campanhas difamatórias, apelo a emoções como ressentimento, ódio e medo, alimentadas por desinformação e culto à personalidade, distraem das discussões essenciais e têm o potencial inflamatório da polarização. A ausência do contraditório e do controle social sobre o conteúdo veiculado favorece uma socialização da radicalização, disseminando modos de ser, agir e pensar que atuam no sentido contrário da construção de consensos e questionam a própria existência da esfera pública enquanto arena do debate racional de ideias.

\section{Notas}

1 Consideram-se como copiados links, vídeos e imagens claramente não produzidos pelos integrantes que postaram o conteúdo e textos cuja presença foi notada em outros grupos monitorados pelo pesquisador.

2 Julgou-se que uma quinta função metalinguística apresentada por Cesarino (2019b), o "espelhamento do inimigo e inversão de acusações”, dizia respeito mais à forma que ao conteúdo das mensagens. A opção foi incluir a estratégia na análise das estratégias discursivas.

3 Tradução do autor: "nasce assim a era da infoxicação, na qual a audiência recebe o conteúdo que deseja - geralmente de infoentretenimento - a fim de garantir cotas de publicidade, ao mesmo tempo em que os próprios destinatários são incapazes de realizar uma filtragem correta de informação, aceitando como certas aquelas que são até contrárias a outras que já aceitaram como verdadeiras. Parece então que chegamos a compreender que a desinformação é uma situação estrutural do ecossistema midiático e que as audiências, paradoxalmente, emergem como vítimas propiciatórias desse fenômeno".

4 Tradução do autor: "Não devemos subestimar esses movimentos devido a seu ínfimo nível intelectual ou à falta de teorização. Seria uma enorme falta de visão política pensar que é por isso que eles não terão sucesso. A característica desses movimentos é antes uma extraordinária perfeição da mídia, e especificamente em primeiro lugar a mídia propagandística no sentido mais amplo, combinada em tal perfeição de técnicas e mídia, enquanto se escamoteia o fim que realmente é perseguido pela sociedade em geral”.

\section{Referências}

ADORNO, T. W. Rasgos del Nuevo Radicalismo de Derecha. Barcelona: Taurus, 2020.

ALVES, C. Temendo o STF, bolsonaristas batem recorde de sumiço de vídeos do YouTube. UOL, 2020. Disponível em: https://noticias.uol.com.br/colunas/chico-alves/2020/07/07/temendo-o-stf-bolsonaristas-batem-recorde-de-sumico-de-videos-do-youtube.htm. Acesso em: 25 de jun. 2020.

ARBEX, T.; URIBE, G. 'Gabinete da raiva’ perde espaço no Planalto após alta da reprovação de Bolsonaro. 2019. Disponível em: https://www1.folha.uol.com.br/poder/2019/09/gabinete-da-raiva-perde-espaco-no-planalto-com-alta-de-rejeicao-a-bolsonaro.shtml. Acesso em: 29 jun. 2020. 
CAMPOS MELLO, P. Empresários bancam campanha contra o PT pelo WhatsApp. Folha de $S$. Paulo, 18 de outubro de 2018. Disponível em: https:/www1.folha.uol.com.br/poder/2018/10/empresarios-bancam-campanha-contra-o-pt-pelo-whatsapp.shtml. Acesso em: 21 fev. 2020.

CAMPOS MELLO, P. WhatsApp admite envio maciço ilegal de mensagens nas eleições de 2018. Folha de S. Paulo, 8 de outubro de 2019. Disponível em: https://www1.folha.uol.com.br/ poder/2019/10/whatsapp-admite-envio-massivo-ilegal-de-mensagens-nas-eleicoes-de-2018.shtml. Acesso em: 21 fev. 2020.

CESARINO, L. Como vencer uma eleição sem sair de casa: a ascensão do populismo digital no Brasil. Internet \& Sociedade, v. 1, n. 1, p. 91-120, 2019a.

CESARINO, L. Identidade e representação no bolsonarismo: corpo digital do rei, bivalência conservadorismo-neoliberalismo e pessoa fractal. Revista de Antropologia, v. 62, n. 3, p. 530-557, 2019b.

CESARINO, L. Pós-verdade: uma explicação cibernética. Dossiê VII Reunião de Antropologia da Ciência e da Tecnologia. Ilha Revista de Antropologia, v. 23, n. 1, p. 73-96, 2021.

CHAGAS, V.; MODESTO, M.; MAGALHÃES, D. O Brasil vai virar Venezuela: medo, memes e enquadramentos emocionais no WhatsApp pró-Bolsonaro. Esferas, n. 14, p. 1-17, 2019.

CHAPARRO, M. C. Sotaques d'aquém e d'além mar: travessias para uma nova teoria de gêneros jornalísticos. São Paulo: Grupo Editorial Summus, 1998.

CHRISTIE, E. H. Political Subversion in the Age of Social Media. European View, v. 18, n. 1, p. 122-122, 2019.

DUDA DA SILVA, E. As bases da nova direita: estudo de caso do Movimento Brasil Livre na cidade de São Paulo (2013-2016). Conversas \& Controvérsias - Revista de Graduação e Pós-Graduação em Ciências Sociais, v. 5, n. 1, p. 75-95, 2018. DOI: http://doi.org/10.15448/21785694.2018.1.30257. Acesso em: 20 de março de 2019.

DURKHEIM, É. Educação e Sociologia. São Paulo: Melhoramentos, 1965.

FAROOQ, G. Politics of Fake News: How WhatsApp Became a Potent Propaganda Tool in India. Media Watch, v. 9, n. 1, p. 106-117, 2018.

GARIMELLA, K.; TYSON, G. WhatApp Doc? A First Look at WhatsApp Public Group Data. 2018.

GIDDENS, A. As consequencias da modernidade. São Paulo: Unesp, 1991.

GIDDENS, A. A vida em uma sociedade pós-tradicional. In: BECK, U. et al. (ed.). Modernização reflexiva. São Paulo: Unesp, 1997. p. 73-133.

HAN, B.-C. No enxame. Petrópolis: Vozes, 2018.

JENKINS, H. Convergence Culture. Where old and new media collide. Nova York; Londres:

New York University Press, 2006.

KALIL, I. O. O que são e no que acreditam os eleitores de Jair Bolsonaro. 2018.

LACLAU, E. A razão populista. São Paulo: Três Estrelas, 2013. 
LAHIRE, B. Homem plural: os determinantes da ação. Petrópolis: Vozes, 2002.

LAHIRE, B. Retratos Sociológicos - disposições e variações individuais. Porto Alegre: Artmed, 2004.

LAHIRE, B. Monde pluriel. Paris: Seuil, 2012.

LIBÂNEO, J. C. Pedagogia e pedagogos, para quê? São Paulo: Cortez, 1998.

LITZENDORF NETTO, C. F. W.; PERUYERA, M. S. Fake News como ferramenta de propaganda política na internet. In: Intercom - Sociedade Brasileira de Estudos Interdisciplinares da Comunicação; XIX Congresso de Ciências da Comunicação na Região Sul, Cascavel, PR, 2018.

MATSUKI, E. Bolsonaro acabou de criar o Tribunal Constitucional Militar para caçar os corruptos \#boato. Boatos.org, 2020. Disponível em: https://www.boatos.org/politica/bolsonaro-acabou-criar-tribunal-constitucional-militar-cacar-corruptos.html. Acesso em: 25 jul. 2020.

MCNAIR, B. Journalism and democracy. In: WAHL-JORGENSEN, K.; HANITZSCH, T. (ed.). The handbook of journalism studies. Nova York: Routledge, 2009. p. 237-249.

MIGUEL, L. F. A reemergência da direita brasileira. In: SOLANO, E. (ed.). O Ódio como Políti$c a$ : a reinvenção das direitas no Brasil. São Paulo: Boitempo, 2018. p. 26-53.

MORAES, M. \#Verificamos: É falso que cubano recebendo extrema unção era fazendeiro executado sem julgamento. Agência Lupa, 2019. Disponível em: https://piaui.folha.uol.com. br/lupa/2019/09/19/verificamos-cubano-extrema-uncao-fazendeiro-executado/?aff_source=56d95533a8284936a374e3a6da3d7996. Acesso em: 25 jul. 2020.

NEMER, D. Grupos pró-Bolsonaro no Whatsapp não se desmobilizaram com a vitória. Pelo contrário, estão mais radicais. 2019. Disponível em: https://theintercept.com/2019/08/23/grupos-pro-bolsonaro-whatsapp-estao-mais-radicais/. Acesso em: 21 fev. 2020.

PIAIA, V.; ALVES, M. Abrindo a Caixa Preta: análise exploratória da rede bolsonarista no WhatsApp. 2019. Disponível em: http://compolitica.org/novo/wp-content/uploads/2019/05/gt2_ Piaia_Alves.pdf. Acesso em: 21 fev. 2020.

PINHEIRO, M. M. K.; BRITO, V. D. P. Em busca do significado da desinformação. DataGramaZero - Revista de Ciência da Informação, v. 15, n. 6, 2014. Disponível em: http://www.brapci.inf. br/index.php/article/download/51758. Acesso em: 21 fev. 2020.

RATIER, R. P. Broadcast e radicalização para as massas: produção e difusão de conteúdo no WhatsApp bolsonarista. In: ENCONTRO ANUAL DA COMPÓS, 29. Campo Grande: Universidade Federal de Mato Grosso do Sul, 2020.

RATIER, R. P. Império opaco: mapeamento da expansão da rede bolsonarista no WhatsApp. Verbum: cadernos de pós-graduação, v. 9, n. 2, p. 42-58, 2020.

REICH, Wilhelm. Psicologia de Massas do Fascismo. São Paulo: Martins Fontes, 1988.

RESENDE, G. et al. (Mis) Information Dissemination in WhatsApp: Gathering, Analyzing and Countermeasures. ACM. 818-828. 2019.

RIBEIRO, M. M.; ORTELLADO, P. O que são e como lidar com as notícias falsas: dos sites de notícias falsas às mídias hiper-partidárias. Sur - Revista Internacional de Direitos Humanos, v. 
15, n. 27, p. 71-83, 2018. Disponível em: https://sur.conectas.org/o-que-sao-e-como-lidar-com-as-noticias-falsas/. Acesso em: 21 fev. 2020.

ROMERO-RODRIGUEZ, L.; DE-CASAS, P.; PEDREIRA, M. Desinformación e Infoxicación en las cuartas pantallas. In: COMPETENCIAS mediáticas en medios digitales emergentes. Salamanca: Comunicación Social Ediciones y Publicaciones, 2018. p. 73-92.

SCHMITT, C. O conceito do político - a teoria do Partisan. Belo Horizonte: Del Rey, 2009.

SERELLE, M.; SOARES, R. D. L. As novas formas do falso: entretenimento, desinformação e política nas redes digitais. In: XXVIII Encontro Anual da Compós, Porto Alegre, 2019.

SETTON, M. D. G. Mídia e educação. São Paulo: Contexto, 2012.

SETTON, M. D. G. J. A teoria do habitus em Pierre Bourdieu: uma leitura contemporânea. Revista Brasileira de Educação, n. 20, p. 60-70, 2002.

SETTON, M. D. G. J. A educação popular no Brasil: a cultura de massa. Revista USP, n. 61, p. 58-77, 2004.

SETTON, M. D. G. J. A Particularidade do Processo de Socialização Contemporâneo. Tempo Social, v. 17, n. 2, p. 335-350, 2005.

SETTON, M. D. G. J. A socialização como fato social total: notas introdutórias sobre a teoria do habitus. Revista Brasileira de Educação, v. 14, n. 41, p. 296, 2009.

SEUFERT, M. et al. Group-based communication in WhatsApp. IEEE. 536-541. 2016.

SOPRANA, P.; ONOFRE, R.; CAMPOS MELLO, P. Facebook remove contas falsas ligadas a Bolsonaro e gabinete da Presidência. Folha de S. Paulo, 9 de julho de 2020.

THOMPSON, J. B. Ideologia e cultura moderna: teoria social crítica na era dos meios de comunicação de massa. Petrópolis: Vozes, 1995.

VIEIRA, C.; MELO, P.; MELO, P. O. V. D.; BENEVENUTO, F. O Paradoxo da Viralização de Informação Criptografada no WhatsApp. 2019. Disponível em: http://homepages.dcc.ufmg.br/ fabricio/download/sbrc2019-whatsapp.pdf. Acesso em: 21 fev. 2020.

WAJNGARTEN, F. O ódio e a liberdade de expressão. Folha de S. Paulo, 2020.

WHATSAPP. Stopping Abuse: How WhatsApp Fights Bulk Messaging and Automated Behavior. 2019. 